Issue no. $25 / 2018$

\title{
THE FRENCH-GERMAN APPROACH ON THE FUTURE OF THE EUROPEAN UNION
}

\author{
Andreea STRETEA
}

PhD Student

Faculty of European Studies, Babeș-Bolyai University

andreea_stretea@yahoo.com

\section{DOI:10.24193/OJMNE.2018.25.08}

\begin{abstract}
The European political scene became uncertain in recent years, as several crises shook the continent from the ground. Starting with the BREXIT and the rise of populist parties all over the European continent and continuing with the migration crises, the Eurozone crises etc. - all of these led to the emergence of several scenarios and proposals for the future of the European Union. France and Germany were always at the core of the decision-making process, as they are two of the most important and powerful member states inside the Union, especially now that UK has decided to leave. Therefore, the rest of the Member States are looking up to them, expecting solutions for this general crises the EU is facing. This article seeks to analyze and determine the importance and influence these two Member States have inside the EU and how are they planning to use that influence in persuading others on following their action plans. Is it possible they join forces and start working together properly towards a common goal, or their historical past will catch up to them preventing them to think about the general wellbeing of the Union and the greater good?
\end{abstract}

Keywords: France, Germany, EU, future, partnership

\section{Introduction}

60 years have passed since the Treaty of Rome was signed. What has come to be known as the European Union has developed through the years, but what seems to remain constant is the perpetual crises that takes place inside the continent. As Jean Monnet stated "Europe will be forged in crises, and will be the sum of the solutions adopted for those crises" (The Economist, 2018). 
Issue no. $25 / 2018$

UK's decision to leave the European Union left the other 27 Member Stats in shock and took them by surprise, as nobody was expecting a country will ever leave this supranational organization that is the EU. UK's decision shouldn't come as a surprise, though, as it is well known - both for the European elites as well as for the general public - that UK never actually connected and shared the European values promoted inside the Union. It is also known that this relationship was damaged even before it started, if we remember UK's double failed attempt to join the EEC - at the time - and the "empty chair crises" where French president Charles de Gaulle used his veto right twice to prevent it from joining. After UK eventually managed to join it was struggle after struggle and compromise after compromise from both sides, as almost immediately after becoming a member UK held a referendum to exit the Union - that didn't happen at the time - but lead to the acceptance of several opt-out decisions from the UK, including the opt-out from the Eurozone. It seemed that both parts were struggling to make this relationship work, but eventually the rope was too tight and pressure eventually caught up to them, resulting in the British exit, or BREXIT from the Union.

Given the history, some would have thought that UK's departure would affect the EU to the point of dissolution, but the exact opposite happened, as recent developments, speeches and policy actions show that the remaining 27 Member States decided to turn to flexibility as the driving force that will keep the EU up and running in the post-BREXIT era. What BREXIT has thought European leaders is that the EU should evolve and become less elitist and centralized, and more flexible, focused on its citizens and their needs from all across Europe. BREXIT was a start that could become an incentive for other European countries to leave, if a common ground isn't reached and a major reformation of the whole European project isn't started (De Witte, 2017).

Another effect of this elitist and centralized organization, that seems to be impenetrable and incomprehensible for the broad public, is the rise of Eurosceptic and populist parties. One of the reasons why these right-wing movements and political parties are so popular, and on the rise nowadays, is because they promise the return to the system of European nation state we had in the $19^{\text {th }}$ century and at the beginning of the $20^{\text {th }}$ century. What the average citizen may not know and can be easily fooled with these empty promises 
Issue no. $25 / 2018$

is that this reversion is impossible because of one simple reason: globalization. Politics, economy, the judicial systems communication and cultures have become too interconnected and interdependent, that even Marine Le Pen would hit a concrete wall if she tries to reverse them at this stage of the game. And not only she would hit a wall, but she would also loose the support of her electorate in the process. On the other hand, nation states remain the main form of organization, in spite of this globalization phenomenon the world is facing. Even in this supra-national structure that is the EU, sometimes the nation state is what is needed, as is far stronger than this hybrid structure. Let's take the 2008 financial crises for as an example, where the nation state was the only actor that had all the required instruments (financial, legal and political) to face that crises. Of course, the difference between the two structures is that the nation state has a history and culture that tights their citizens and make them feel part of a whole. Also, there is intense communication not only between the state and its citizens, but also between citizens themselves. This communication lead to the establishment of a specific national identity. However, national identity can easily become nationalism when people feel marginalized and underprivileged in structures such as the EU. Not having a communication established, even regulated between European citizens we can't really talk about a European community where average citizens discuss their common issues (Wahl, 2016, pp.158-161).

It was easy for the populist parties to find this crack and infiltrate in it as militants against the European project (that is held reasonable for everything bad that happens at national and European level), and in favor of referendums on European and Eurozone membership, where people feel they have a voice that's heard.

Another reason for this success is the general gloom that took over the European economy. Even though the Eurozone is more or less stable now and there is a certain economic growth, in some parts of the continent growth rates are still low, unemployment still high and public depth remains large across the Union. All of these unsolved issues are due to the fact that the architecture of the Eurozone is still incomplete and the common ground on the matter is still nowhere to be found. If we sum up the migration crisis that still remains an issue among Member States, the foreign and security policy that is still not properly regulated, the democratic deficit and, maybe the biggest problem of them all - EU's 
Issue no. $25 / 2018$

unpopularity among both Member States and its citizens - we can say that the EU has enough to deal with for at least another 60 years (The Economist, 2018, p.2).

European leaders that were commemorating on $25^{\text {th }}$ of March 2017, in Rome, the $60^{\text {th }}$ anniversary of the European Economic Cooperation Treaty, are more than aware of these issues, and together with the EU institutions they have adopted the Rome Declaration where they plead for unity, flexibility and evolution, as a way to ease the tension between Member States and start solving the problems the EU is facing at the moment: "We will act together, at different paces and intensity where necessary, while moving in the same direction, as we have done in the past, in line with the Treaties and keeping the door open to those who want to join later" (Aamann, 2018).

BREXIT was just a warning of what could happen if things keep working the same way, and if change and reformation is not pursued. For this purpose, several European leaders and citizens have turned to France and Germany as the most powerful states inside the Union, the basis of the whole European project and the most plausible actors that can relaunch this project. Therefore, in the following chapters I will try and analyze the relationship between the two countries and how this new Franco-German initiative that was so talked about lately, will influence the future of the EU.

\section{The Franco-German relationship through the years}

Even though 2017 was a troubled year for the EU, the Franco-German relations saw a re-boost of their bilateral relations and a determination from both countries to lead the EU Member States towards the future of the European project.

The relationship between the two powers weren't always defined by cooperation and friendship. As we have come to know, the beginning of the European project was in fact an attempt from French and German leaders to bring the differences and fights between them to an end. The two countries were enemies even before the Second World War, which only contributed to increase the animosity floating in the air. If Germany was always considered the European enemy, the country that everyone from the continent, and beyond, was fearing, France was always a strong supporter of the European idea, but mostly on European 
Issue no. $25 / 2018$

unification - under its leadership if possible. Many countries were looking up to France as an example to follow in terms of European values, culture and democracy.

As a result, at the end of the Second World War, France decided to step up and regain the power it used to have inside the continent. Jean Monnet and Bernard Clappier started working on a plan of European unification, but as they were no diplomats it was little what they could do, not to say almost impossible to convince European leaders to join resources and create a community that will eventually end conflicts between nation states inside the continent. This is where Robert Schuman - a respected French lawyer and politician, which at the time was France's Minister of Foreign Affairs - comes into play.

The Schuman Declaration, the first and most symbolic milestone in the FrancoGerman relationship after the Second World War, was a call to put together France and Germany's coal and steel resources under a supranational umbrella. As Schuman outlined in his declaration the pooling together of these two resources will "make war not only unthinkable, but materially impossible" (European Union, 2018). As he not only called for Franco-German reconciliation, but also he made a call for other European countries to join the movement - because in his own words "the coming together of the nations of Europe requires the elimination of the age-old opposition of France and Germany" (European Union, 2018) - the date he held the declaration, 9 May, is the day the continent celebrates Europe Day. As a result of this declaration and call for unity the European Coal and Steel Community was created (in 1951), which subsequently developed into the European Economic Community (EEC) and later on the European Union.

The initiative was a real success as from that moment onwards there was no armed conflict or war between any European nation, ever again. Of course this doesn't mean that animosity and competition between France and Germany ended as well. Instead of being a Franco-German agreement of equals, the Schuman Plan was an exclusively French initiative that was automatically approved by Germany, without further consideration, because the German government was desperate to find an opportunity to redeem itself and re-enter the European arena after the war. Of course France didn't trust Germany at that point, but instead of continuous conflict with its neighbor, France decided to reverse its foreign policy and start 
Issue no. $25 / 2018$

a constructive cooperation with Germany, a cooperation that would benefit both sides (Mourlon-Druol, 2017, pp. 4-5).

After this historic moment it was a continuous political ping-pong between the two powers. Since the break-up of the Soviet bloc and the German reunification, France saw its power inside the continent and the community threatened, even though it never actually lost its position on the global arena. It was no longer France calling the shots the way it pleased and to its best convenience. Therefore, it came up with a plan of European integration, mainly through the creation of a single European currency (Lefebvre, 2004, p.1).

The growing instability of the currency at international level in the '70s showed the need to come up with a plan, inside the EEC, that can reintroduce stability within the monetary relations Member States had. The German chancellor at the time, Helmut Schmidt, together with his government managed to reach an agreement with the French president, Giscard d'Estaing, after several attempts made by the French government through several proposals that were rejected by the Germans. In 1978 both countries took the lead and developed a new European currency framework - the European Monetary Fund (EMF). This initiative enabled deeper integration within European countries. But then again, this agreement wasn't an equal one either, as it represented exactly what the German government wanted and what it was ready to agree on, preferences the French government only validated (Mourlon-Druol, 2017, p.6).

It is true that through the years several disagreements and compromises between the two nations took place, but eventually their relationship stands for reconciliation, peace and solidarity. Inside the EU the Franco-German couple represents the political leadership of the Union. This leadership promotes European integration, deals with political crises management and establishes subgroups within the member States. All of the in an effort to solve Europe's crises. As a way to formalize the bilateral relationship and to increase the cooperation between the two countries, French president Charles de Gaulle and the German chancellor Konrad Adenauer signed on January 22, 1963 the Elisée Treaty. Through this Treaty they committed to consult each other on all important matters that might require a common position (Valant, 2017, p.1). Even though the Treaty was an important moment in the couple's history, it actually had very little results. More than an actual Treaty, it is the 
Issue no. $25 / 2018$

symbolism that lays beneath this agreement that is important. This is why it was renewed and revised every once in a while, to be able to meet the demands of the time. For instance, the revision of the Treaty made in 2003 created a Franco-German Ministerial Council and developed a Franco-German history textbook (Mourlon-Druol, 2017, p.4).

Nowadays, the current Franco-German leaders - Emmanuel Macron and Angela Merkel - are revising the Elisée Treaty, after the French president made a call to the German chancellor during his Sorbonne speech, in September 2017. Therefore, on January 19, the two leaders agreed in Paris to draft a new version of the Treaty, as a way to mark its $55^{\text {th }}$ anniversary (Files, 2018) but also as a statement for the EU Member States and the rest of the world, showing that they have started to make the first steps towards deeper cooperation and that they are ready to take the lead in the process of European reconstruction. ${ }^{25}$

There are plenty of examples of this tight cooperation between these countries, and how their respective leaders managed to find a way to work together in and for different circumstances. We'll discuss more about these Franco-German political leaders and their actions in an attempt to understand the current leadership of the Franco-German axis, in the following part of article.

\section{The Franco-German power couples and their contribution to the future of}

\section{the EU}

During these 60 years we've witnessed several ups and downs in the Franco-German relationship and their quest for European supremacy. However, both countries - especially through their leaders - have influenced the European integration process. We will try and analyze the relationships between those leaders and their input regarding the changes made at European level.

The ones who lead the pack and were the first couple willing to cooperate with each other were Charles de Gaulle and Konrad Adenauer. They set the tone of this reconciliation process, when de Gaulle invited Adenauer to his home in Colombey-les-Deux-Églises, in

\footnotetext{
${ }^{25}$ For the full joint declaration, please consult "L'amitié Franco-Allemande est l'affaire de tous ! Emmanuel Macron", YouTube, https://www.youtube.com/watch?v=RXbcAYxuZxw, accessed 16 march 2018.
} 
September 1958. Adenauer was the first and only world leader to step foot in de Gaulle's personal home, a move cautiously and smartly made by the French President to convey the idea that war and enmity between the two countries should be replaced by trust, respect and mutual understanding. Also, the Élysée Treaty was designed under their leadership and they were the first leaders to sign this treaty, providing an example and setting a precedent for the future Franco-German leaders that followed (Mourlon-Druol, 2017, p.3).

Personal connections were critical for this reconciliation process and President Giscard d'Estaing and Chancellor Schmidt shared a true friendship that helped not only their respective nations, but also the whole European project during their time in office, when the European Council was created (1974) and the basis for the European Monetary System were put (1979) (Valant, 2017, p.2).

Another important mention is the Mitterand-Kohl couple, which was responsible for the internal market and the Single European Act (1986), therefore for future integration of the European countries. During their leadership the Europeanisation of Germany resurfaced as a priority and a goal for the country that was once seen as the plague of Europe. This shift in policy was due to several reasons, but the central pawn that made all of this possible was Chancellor Kohl. He had a clear vision and made considerable efforts to reinforce Germany's European identity, which would have been impossible without the French contribution (Bulmer and Paterson, 1996, p.13).

The following time frame saw the Franco-German relations struggle, due to the German unification that left France significantly weaker inside the Community, and Germany started to question its role in Europe. Therefore, the Maastricht Treaty (1993) say a stronger Germany ready to fight for its interest, and a weaker France in the face of the newly unified Germany. Agreements between French President, François Mitterand and German Chancellor Helmut Kohl were critical at a time when the creation of a Single European Currency was discussed. However, at the end of the negotiations, when the time to sign the Treaty came, we can say that the French and German governments agreed to disagree on several important issues, and as a result there is, even nowadays, an incomplete monetary union (MourlonDruol, 2017, p.6). 
Issue no. $25 / 2018$

Given the fact that the Franco-German couples are by far the most influential inside the EU, it is no surprise that there is a continuous competition between the two, regarding whom holds most of the power. It is true that France was always frightened by the German power and following the say "keep your friends close and your enemies closer", decided to join forces with Germany, instead of fighting it - in a context where France knew that little were its chances to win that fight. On the other hand, Germany always envied France in terms of culture, architecture, literature etc. and always felt the need to compete on these areas and in many others.

Partly, one of the reasons France always wanted to take European Unions' lead was because of this fear of the German power. As an example in this regard, is the 2000 Nice Summit, where France insisted on an equal voting weight with Germany in the Council of Ministers (Lefebvre, 2004, p.1). The Chirac-Schröder agreement from 2002 regarding the constitutional convention seemed to get things back to normal and on the right track for both countries, but their divergent positions regarding EU's interior design - the path and policies that should be followed - lead to the negative outcome of the Constitutional Treaty in 2005, when it was rejected by both France and The Netherlands (Valant, 2017, pp. 2-3).

As we can see, the current leadership of these two countries - Emmanuel Macron and Angela Merkel - has a high bar to stand up to, when they have such important political figures that precede them and managed to become a part of the world's history. The pressure is even higher for the two leaders, as the Franco-German couple is the driving engine of the EU - the relationship that stands at the core of the European integration. In today's European environment, that faces several crises, this long time alliance needs to step up and provide the much desired, but also much needed leadership that surpasses national of historical divergences, in this process that will forge the future of the EU.

There are two areas I have selected as case studies for establishing the decisions and measures that have been and will be made in several policy areas. I will analyze the Eurozone crises and the Foreign and Security Policy and try to establish how the Macron-Merkel couple input and influence shapes and tries to solve these policy areas. 
Issue no. $25 / 2018$

\subsection{The Eurozone Crises}

As I have stated before, the Maastricht Treaty created an incomplete monetary union, which represent the starting point of Eurosceptic beliefs. In their view the treaty was only an agreement between France and Germany, where France accepted the German unification and in return Germany accepted to give up the Douche mark and exchange it for the Euro.

This move may have seemed restless at the time, but by launching the Euro in 1999and replacing national currency with it in 2002, the EU was taking a huge step towards deeper political and economic integration between Member States (The Economist, 2018, p.4).

Everything went well for a while, but then, after the 2008-2009 recession, several issues and inconsistencies of the Eurozone started to (re)surface. Even though several measures were taken, it appears that the results are still not the expected ones as unemployment rates are still high in most of the EU Member States, and the modest growth rate won't help solve this issues that the austerity created. During this crisis it became more than clear that the European institutions are unprepared to solve debt issues, and also it became clear that the withdrawal from the Eurozone was never considered, therefore there are no clear rules in this cases where the very existence of the common currency was called into question. The European Central Bank interfered immediately, at its interference was a success, but its limitations were brought to light during the process. After this economic stagnation was all over Europe, except for Germany, especially in countries such as Portugal, Italy, Greece and Spain. The introduction of the Euro in 2002 was a good and important step for the EU, but it didn't solve the differences that were already there, between the Member States of the Eurozone, and the economic crises only magnified the already existing imbalance. It also managed to call into question the existence of the Eurozone and to show the desperate need for reform, as the economic integration has serious limitations that together with the common currency are the roots of this perpetual crisis Europe is facing nowadays (Gualerzi, 2017, pp. 394-397).

The election of the centrist, pro-European, Emmanuel Macron as the French President brings new hope on the continent, as the Franco-German renewed leadership can now help the EU take steps forward and solve the existing crises. Starting with the Eurozone, as the 
Issue no. $25 / 2018$

obvious first choice, the road won't be an easy one. The differences between the FrancoGerman economic philosophy are not the only obstacles that need to be surpassed. Even though the Euro was a Franco-German initiative, the couple has disagreed through the years on how to solve the problems the Eurozone is facing. Germany has always wanted stricter rules regarding government budgets. France, however, always looked for common instruments and more active microeconomic policies, even though most of the times these ideas were ignored by Germany (Grant, 2017).

When Macron was part of Hollande's government, he had a strong view regarding the Eurozone reformation, calling for elements such as transfer union, risk-sharing and demand management at Eurozone level. He keeps the same ideas even now that he became President of the Republic, but in order for this ideas to actually be implemented, Germany has to approve them. And Germany has different views on managing the Eurozone economics. It opposes any kind of transfer union, wants stricter compliance with budgetary rules and argues that Member States should not be bailed out unless holders of their sovereign bonds take losses (Grant, 2018).

Therefore, Macron knows that shifting Germany's policy will not be an easy job, as German hostility to the Keynesian system is undiminished. Yet, France remains optimistic in this project of Eurozone reformation. The plan is to complete the banking union by the end of the year, which is challenging due to the fact that deposit insurance is incompatible with banks practice of holding large amounts of their government's debt (Gros, 2017). Later on they should deal with the transformation of the European Stability Mechanism (ESM), a bailout fund into a European Monetary Fund, establish a Eurozone budget and institutional reforms such as the creation of a Eurozone finance minister. The French know that the idea of a Eurozone finance minister is not a very popular one, not only in Germany, but also in several other Member States, so they describe this initiative as the "end of the process", therefore they expect a compromise on the matter from both sides (Grant, 2018, p.3).

All in all, the euro remains a troubled currency, whose direction is uncertain, but there is a general agreement that the Eurozone needs further integration. The disagreement appears on how to accomplish this integration. Germans do not share the French taste for flexibility in terms of fiscal policy as they prefer discipline and rules (The Economist, 2018, p.7). Still, 
Issue no. $25 / 2018$

Merkel will probably agree to some of Macron's demands, especially if he achieved reform in France, mainly because of the EU's power politics and because Germany needs France as a strong partner to run the EU, now that UK decided to depart (Grant, 2017, p.2).

\subsection{Foreign and Security Policy}

When it comes to EU's Common Foreign and Security Policy (CFSP) the FrancoGerman couple is more limited because the subject is such a sensitive one, both for the couple and for other global powers. Also, the cultural and strategic differences between the two, are some of the reasons why they haven't managed to reach a total consent on the matter.

Even though the CFSP dates since 1999 when France and Germany signed a joint proposal on the matter, there are still several important issues they couldn't solve, even nowadays. Progress has been made in the last couple of years, but their diverging concepts on the matter don't allow them to move forward. One of the first most important moments in the Franco-German security cooperation history was in 2003 when both of them refused to invade Iraq together with America (Valant, 2017, p.5). Since then, at a European level, the only success they've managed to achieve was in 2016 when the Franco-German couple managed to convince their partners that the Union needs an exhaustive reform in the Common Security and Defense Policy area. In 2017 they've also agreed on establishing a Military Planning and Conduct Capacity (Kempin and Kunz, 2017, p.8). Apart from this, little has been made on this field.

If they manage to come up with a solid action plan this will benefit not only EU's Security and Defense Policy, but also it could add value and it could help in the future consolidation of the Franco-German partnership. Since Macron took office, the two countries have started to work hard on CSDP matters, issuing a joint declaration in September 2017, and also starting to work on a new version of the Elisée Treaty which is important as a statement and a way to influence several other nations to consider and join the plan and to realize that security matters are becoming more and more important for the EU. Through this plan they are trying to give a new impulse to the EU in terms of defense and security, by introducing new cooperation mechanisms such as the Permanent Structured Cooperation 
Issue no. $25 / 2018$

(PESCO) (Frontini, 2017). PESCO will allow Member States - with high military capacity to closer cooperate outside the EU 27.

If they play their cards right, a security and defense partnership between these two countries inside the EU will be the true start of the European project, especially considering the treats and challenges the Union is confronting with at present. Therefore, if they want success in the matter, a permanent dialogue between Paris and Berlin should be established fulfilling the provisions made in 1963's Elisée Treaty. The partnership shouldn't only be about discussions and plans, but also it should be an institutionalized, or at least have organized and planned regular meetings, between the two, that could also serve as a way to facilitate communication between parliaments and military/diplomatic representatives (Kempin and Kunz, 2017, p.13).

Either way, the cooperation between France and Germany in terms of security and defense (but not only), should represent a starting point for a more inclusive European project. Unity inside the EU seems to be the biggest problem at the moment, a moment when it should be more important than ever. With the treats existing both inside and outside the Union, security and defense become more and more important every day for the EU nations, and the Franco-German couple seems the only plausible option for managing to take the lead and bring the Member States together, in a joint action against the forces that treat the EU.

\section{Conclusion}

BREXIT has raised several issues among EU's Member States and has also resurfaced some of the old problems the Union was confronting with. Since the creation of the European Coal and Steel Community, the emphasis was on the Franco-German tandem, as an example of unity, integration, integrity and indivisibility.

France and Germany are the two largest and more powerful EU countries (especially now that UK has decided to exit the Union). As large countries, that have powerful and diverse economies the couple would be able to face the BREXIT costs by themselves, and would be also willing to "take a hit for the greater good" and for their main strategic interest - the European Union (Springford, Lowe and Oppenheim, 2018). 
Issue no. $25 / 2018$

The couple saw their position inside the EU as guardians and models for other Member States in the integration process. Their leaders' position was a continuous one through the years. At the beginning they took this leader position involuntary as the continent reconciliation depended on the Franco-German reconciliation. As time passed they started to take this leadership position deliberately with the purpose to straighten the integration process and the EU as a whole. The importance of this leadership is visible the most in their joint effort to save the Eurozone. In terms of Foreign and Security Policy it is more than visible that their influence and their actions are more limited. Both of the countries are also involved in other organizations and decision-making mechanisms, this together with the fact that their national foreign and security policies are so different, makes is really difficult for them to reach a common strategy in the matter.

On the other hand, relying only on the Franco-German couple is a mistake that the EU should be careful not to make. Leaving the rest of the Member States on the side and not involve them in the decision-making process, as much as they should be, is dangerous for the Union as it will only help the disintegration process to deepen and spread across the continent. As important as France and Germany are for the EU, they still can't be the only ones deciding for all 27 Member States. Allowing this could mean that they may try and implement their national policies and/or preferences, and even though they work for Germany and/or France that doesn't mean those policies would work for other Member States as well. There are several other factors that need to be taken into account, such as their economic and political history, for instance.

The ideal scenario would be that through this Franco-German partnership, especially the new EU power couple - Macron and Merkel - they manage to mobilize other Member States to work together towards a common goal - improving the EU and build a better future for the European generations to come. If in the past the basis for any European disagreement were France and Germany, in the future the two countries should become the basis for any improvement inside the European continent. 
Issue no. $25 / 2018$

\section{References}

- AAMANN, P. (2018). The Rome Declaration - Consilium. [online] Consilium.europa.eu. Available at: http://www.consilium.europa.eu/en/press/pressreleases/2017/03/25/rome-declaration/ [Accessed 15 Mar. 2018].

- $\quad$ BULMER, S. and PATERSON, W. (1996). Germany in the European Union: gentle giant or emergent leader? International Affairs, 72(1), pp.9-32.

- $\quad$ DE WITTE, B. (2017). The future of variable geometry in a post-Brexit European Union. Maastricht Journal of European and Comparative Law, 24(2), pp.153-157.

- $\quad$ European Union. (2018). The Schuman Declaration - 9 May 1950 - European Union

- European Commission. [online] Available at: https://europa.eu/european-union/abouteu/symbols/europe-day/schuman-declaration_en [Accessed 16 Mar. 2018].

- $\quad$ FILES, C. (2018). Élysée Treaty - 55th anniversary (22.01.18). [online] France Diplomatie: Ministry for Europe and Foreign Affairs. Available at: https://www.diplomatie.gouv.fr/en/country-files/germany/events/article/elysee-treaty-55thanniversary-22-01-18 [Accessed 16 Mar. 2018].

- $\quad$ FRONTINI, A. (2017). 'The 'Macron effect' on European defense: En Marche, at last?'. [pdf] European Policy Centre. Available at: http://aei.pitt.edu/87776/1/pub_7723_macroneffectoneuropeandefence.pdf [Accessed 9 Mar. 2018].

- $\quad$ GRANT, C. (2017). Macron, Merkel and the future of the euro. [pdf] CER Bulletin. Available at: http://www.cer.eu/sites/default/files/bulletin_114_cg_article2.pdf [Accessed 15 Feb. 2018].

- GRANT, C. (2018). Macron's plans for the euro. [pdf] CER Insight. Available at: https://www.cer.eu/sites/default/files/insight_CG_23.2.18_fin_0.pdf [Accessed 5 Mar. 2018].

- $\quad$ GROS, D. (2017). Macron's victory brings new hope across Europe on several fronts. Centre for European Policy Studies (CEPS). Brussels.

- GUALERZI, D. (2017). Crisis in the Eurozone: Austerity and Economic Transformation. Review of Radical Political Economics, 49(3), pp.394-409. 
Issue no. $25 / 2018$

- $\quad$ KEMPIN, R. and KUNZ, B. (2017). France, Germany, and the Quest for European Strategic Autonomy: Franco-German Defense Cooperation in a New Era. Notes du Cerfa. Paris: Ifri.

- $\quad$ LEFEBVRE, M. (2004). France and Europe: an ambivalent relationship. U.S. Europe Analysis Series. Washington DC: The Brookings Institution.

- MOURLON-DRUOL, E. (2017). Rethinking Franco-German relations: a historical perspective. Policy Contribution, (29), pp.1-10.

- $\quad$ SPRINGFORD, J., LOWE, S. and OPPENHEIM, B. (2018). Will the unity of the 27 crack? Centre for European Reform.

- The Economist. (2018). The future of the European Union. [online] Available at: https://www.economist.com/news/special-report/21719188-it-marks-its-60th-birthdayeuropean-union-poor-shape-it-needs-more [Accessed 15 Mar. 2018].

- VAlANT, P. (2017). The Franco-German couple: Potentials and limitations. In: Theseus Conference. TEPSA.

- WAHL, P. (2016). Between Eurotopia and Nationalism: A Third Way for the Future of the EU. Globalizations, 14(1), pp.157-163.

- YouTube. (2018). L'amitié Franco-Allemande est l'affaire de tous ! Emmanuel Macron. [online] Available at: https://www.youtube.com/watch?v=RXbcAYxuZxw [Accessed 16 Mar. 2018]. 